\title{
Andrological examination of Hungarian Large White and Landrace boars
}

\author{
${ }^{1}$ Eszter Balogh $-{ }^{1}$ László Kern $-{ }^{1}$ István Anton $-{ }^{1}$ Orsolya Balogh $-{ }^{1}$ György Gábor $-{ }^{2}$ József Rátky \\ ${ }^{1}$ National Agricultural Research and Innovation Centre Research Institute for Animal Breeding, Nutrition and Meat Science, \\ Herceghalom, Hungary \\ ${ }^{2}$ University of Debrecen Faculty of Agricultural and Food Sciences and Environmental Management, \\ Institute of Animal Science, Biotechnology and Nature Conservation, Debrecen, Hungary \\ balogh.eszter@athk.naik.hu
}

\begin{abstract}
SUMMARY
The Hungarian Large White and Hungarian Landrace pig breeds have outstanding lifetime performance, production parameters and crossbreeding ability. Nevertheless, during the recent decades, these breeds could not compete with the West European hybrid pigs concerning on production results. In this study, we made a complex andrological evaluation of boars in different Hungarian nucleus breeding stocks. After taking blood and semen samples, performing gonadotropin-releasing hormone (GnRH) challenge, ultrasonic and thermographic examinations were done. Laboratory tests were accomplished in reproduction labs of NARIC ABNMS. Our goal was to determine the reproductive performances of boars and collect samples for future genetic examinations, respectively.
\end{abstract}

Keywords: Hungarian Large White, Hungarian Landrace, sperm quality

\section{INTRODUCTION}

Swine plays an important role from the aspect of food supply and the economy. During the recent decade, around $40 \%$ of the world's meat consumption was pork (Xiaodong et al. 2012). Pigs went through a strong selection in the course of domestication. On global scale, there are several swine races resistant to different environmental factors e.g. cold and hot temperature, various pathogens and diseases. Therefore, these animals can adapt easily to the extreme conditions of their area (Chen et al. 2007). For all breeders, it is very important to achieve the best results of production. One of the most prominent features is reproductive performance. Economic activity can be significantly influenced by the reproductive success. It was detected that cc $30 \%$ of total loss originated from reproductive problems (Stalder et al. 2004). The Hungarian Large White and Hungarian Landrace reportedly have very good life span performance, production parameters and crossbreeding ability. Nevertheless, during the recent decades, these breeds could not compete with the West European crossbreeding pigs concerning production results.

The development of the Hungarian Large White began in the early 1900s, when the predecessors were the English Large White, the German Large White, the English Middle White and the Swedish Yorkshire. The herd-book was established about 100 years ago. This breed belongs to the Breedgroup 1 and the main goal is to increase reproductive performance, growth potential, and feed conversion rate, maintaining robustness, good adaptability, increasing stress tolerance and outstanding meat quality (Horn 1976, Horn et al. 2011).

The Hungarian Landrace was registered in the second half of the $20^{\text {th }}$ century. It has good adaptability, stress tolerance and sensitivity to the given housing method. The outspoken breeding goal is to improve reproductive outcome and lean meat yield.
The maternal line is either pure bred or crossed by Large White (Horn 1976).

\section{The reproductive analysis of boar}

Sperm quality assessment

For successful artificial insemination, all quantity and quality parameters of the semen and sperm cells must be known. Xu et al. (1998) found that the litter size can be influenced by sperm number per ejaculate. Moreover, the number of normal sperms in the ejaculate would have influence on litter size. Alm et al. (2006) demonstrated that the farrowing rate is strongly affected by sperm number per ejaculate. Both studies declared that fertility was lower if the semen dose contained lower sperm number in the course of insemination. Wekerle et al. (1985) investigated the morphology of 30 boars' semen at different parts of the testis and epididymis after castration. Following dilution and smear, they studied the ratio of semen abnormalities. The results of the study showed that the hair pin tail had largest number in the epididymis while in the testis the number of this abnormality was lower. The migration of the cytoplasmic droplets went off in the head of the epididymis and the selective resorption took place in the tale section of the epididymis. As a result of the microscopic examination of semen we can obtain clear information of abnormalities, cell membrane integrity, and acrosome status. These three parameters are indispensable to assess the fertility ability (Donadeu 2004). The most practical method to assess semen motility is using light microscopy or phase contrast microscopy. This method is highly dependent on the personal experience of the researcher running the analysis (Vyt et al. 2004). For the mentioned reason, in addition to visual evaluation, automated evaluation systems (CASA - Computer Assisted Semen Analysis) have been also been developed for proper evaluation. The system provides detailed information on the movements of the spermatozoa, it shows the 
progressive motility, hyperactivity and various subpopulations of sperm within an ejaculate (Verstegen et al. 2002, Rijsselaere et al. 2003).

\section{GnRH test}

Reduced fertility or infertility can be estimated by the examination of boar semen. The individual testosterone production in each animal significantly influences their reproductive performance even within a day; therefore, single sampling does not provide accurate results. However the testosterone response to $\mathrm{GnRH}$ treatment reflects hormone production of boars (Sarlós et al. 2006). GnRH has a high influence on the reproductive function of animals. Post et al. (1987) figured out that response of testosterone has a significantly positive correlation with the fertilizing ability of individuals. Einarsson and Larsson (1980) tested Large White and Landrace boars for blood testosterone levels and they found the testosterone peak $2-4^{\text {th }}$ hour post GnRH. Sarlós et al. (2006) studied Mangalica boars and found that testosterone concentration after GnRH did not reach the same high peak as other breeds. Wekerle et al. (1989) applied a new GnRH which resulted in an increased testosterone concentration in peripheral blood. The relationship between blood testosterone content and the sizes of the testis in boars has already been described by Schinckel et al. (1984) and Schnaider et al. (1988).

\section{Ultrasonic examination}

Ultrasonography is a non-invasive imaging technology based on ultrasound effect enabling the visualisation of the internal structures of the body e.g. tendons, muscles, vessels, organs. As a result, experienced professionals can locate abnormalities. This technology was first introduced to human and veterinary practice in early 80's (Goldberg and Kimmelman 1988). There are several imaging modes (A-mode (Amplitude mode), C-mode, M-mode (Motion mode), Doppler mode, Pulse inversion mode, Harmonic mode), but the most general imaging mode is the B-mode (Brightnessmode). It is also called 2D mode but already 3D ultrasound is available for veterinarians and the 4D was recently introduced to human health institutes (Cobbold 2007). Coulter and Bailey (1988) found ultrasonography to be a non-invasive tool for checking the testicular and epididymal function of beef bulls. Ultrasound did not affect the percentage of progressively motile spermatozoa, primary sperm defects, secondary sperm defects or normal acrosomes, scrotal circumference, testicular consistency, paired epididymal weight.

\section{Thermographic examination}

Infrared thermography detects infrared energy emitted from an object, converting it to apparent temperature, and displaying the result as an infrared image. It is a non-invasive technology that has been used to indicate thermal biometric changes in animal metabolism resulting from increased body temperature and changes in blood flow in response to environmental or physiological conditions. This method can be a useful device and general stress indicator, as well as an indicator of inflammatory processes, pain and disease (McManus et al. 2016).

\section{MATERIAL AND METHODS}

In the present study, andrological and genetical features of Hungarian Large White and Hungarian Landrace pigs are investigated. A genomic analysis is also planned to be performed. On the basis of the expected results, our aim is to improve the breeding potential of pigs and to promote the further breeding activity of Hungarian breeders throughout modern genetic and reproductive examinations. Eighteen blood and sperm samples of 4 nucleus breeding farms were collected. The collection procedure was made by the veterinarian and the inseminator of the farm. Following blood collection, each boar was administered by GnRH injection (in vein, 50 microgram Fertagyl iv. Intervet International B.V., Boxmeer, Netherlands). Blood was repeatedly collected 90 minutes after $\mathrm{GnRH}$ application to determine the production of testosterone of testis and the relationship between the testosterone serum concentration and fertility (Table 1).

Collected samples

\begin{tabular}{|c|c|c|c|c|c|c|c|c|c|c|c|c|}
\hline \multirow{2}{*}{ Farms } & \multicolumn{2}{|c|}{ Blood samples (n) } & \multicolumn{2}{|c|}{ Ejaculates (n) } & \multicolumn{2}{|c|}{ US } & \multicolumn{2}{|c|}{ GnRH } & \multicolumn{2}{|c|}{ CASA } & \multicolumn{2}{|c|}{ Thermography } \\
\hline & HLW* & $\mathrm{HL}^{* *}$ & HLW & HL & HLW & HL & HLW & HL & HLW & HL & HLW & HL \\
\hline A & 3 & 4 & 3 & 4 & 3 & 4 & 3 & 4 & 3 & 4 & 3 & 4 \\
\hline B & 3 & 1 & 3 & 1 & \multicolumn{2}{|c|}{-} & \multicolumn{2}{|c|}{ - } & 3 & 1 & \multicolumn{2}{|c|}{-} \\
\hline $\mathrm{C}$ & \multicolumn{2}{|c|}{-} & 3 & 2 & \multicolumn{2}{|c|}{5} & \multicolumn{2}{|c|}{-} & 3 & 2 & \multicolumn{2}{|c|}{5} \\
\hline D (other breeds) & \multicolumn{2}{|c|}{2} & \multicolumn{2}{|c|}{2} & \multicolumn{2}{|c|}{ 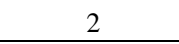 } & \multicolumn{2}{|c|}{2} & & \multicolumn{2}{|c|}{2} \\
\hline Total & \multicolumn{2}{|c|}{13} & \multicolumn{2}{|c|}{18} & \multicolumn{2}{|c|}{14} & \multicolumn{2}{|c|}{9} & \multicolumn{2}{|c|}{16} & \multicolumn{2}{|c|}{14} \\
\hline
\end{tabular}

*Hungarian Large White, **Hungarian Landrace. The table includes 18 samples of animals which were taken on the nucleus breeding farms. We had no possibility to complete every test because of the preceding checks before visiting the breeding farms. At some farms, neither GnRH injection, nor blood sampling I allowed the use of the ultrasound machine and the thermographic camera. The "D" farm is marked with red colour because we only practiced and acquired the basic method there (on other breeds). 
During semen collection, ultrasonic photographs were taken to estimate the morphology of testis (Figure 1) and thermographic photographs (Figure 2) for assessing the heat balance of the testis. The infrared camera can show the temperature with different colours of the whole body and refers to inflamed areas. White shows the warmest areas and blue shows the coldest areas.

\section{Figure 1: Ultrasonic tissue pattern}

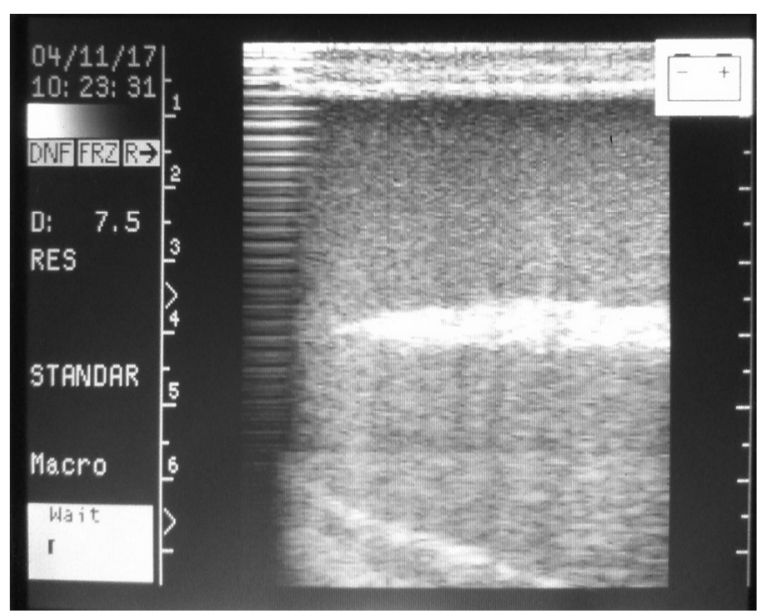

Figure 2: Assessing the heat balance of testis

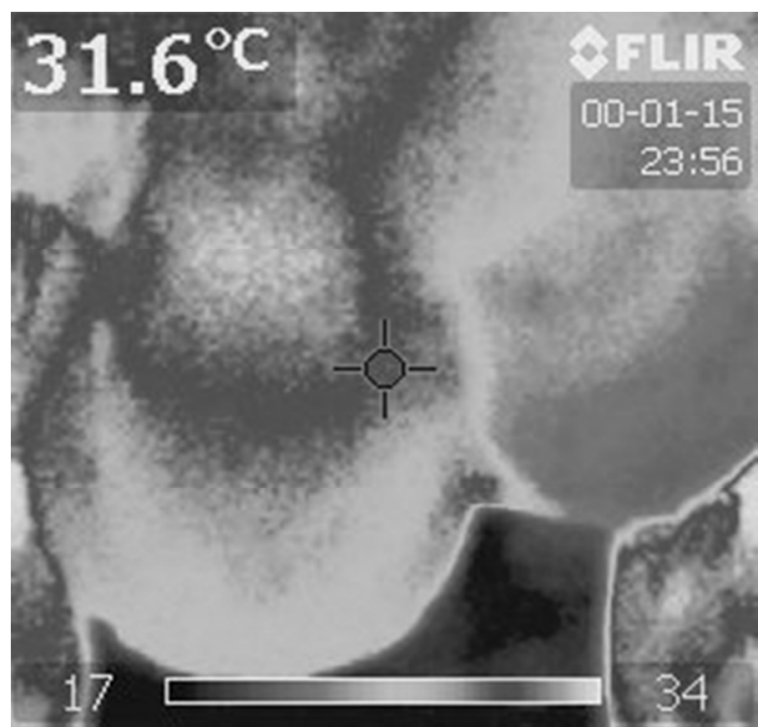

The laboratory work i.e. analysis of spermatozoa morphology, evaluation of the live/dead and acrosome status on stained smear (Kovacs-Foote staining method), investigation of semen motility by CASA (Computer Assisted Semen Analysis) program was performed at by the Breeding and Reproduction Research group, Research Institute for Animal Breeding, Nutrition and Meat Science, National Agricultural Research and Innovation Centre. CASA was used right after the samples were transported from the farms to the institute. The transport temperature was $16{ }^{\circ} \mathrm{C}$. After dilution, we measured the motility of sperms (Figure 5-6). We used regular microscope slide to count approximately 100 cells. The cells were classified in three categories (Non-motile: sperms are not moving. Non-progressive motile: sperms are moving but not going anywhere. Progressive motile: sperms are moving and are getting somewhere).

The Kovacs-Foote staining method was made right after the blood samples were transported to the institute. This method can show the live and dead spermatozoa, the acrosome status and abnormalities of the cells. It can be examined on the stained smear of semen (Figure 3).

Figure 3: Kovacs-Foote staining method

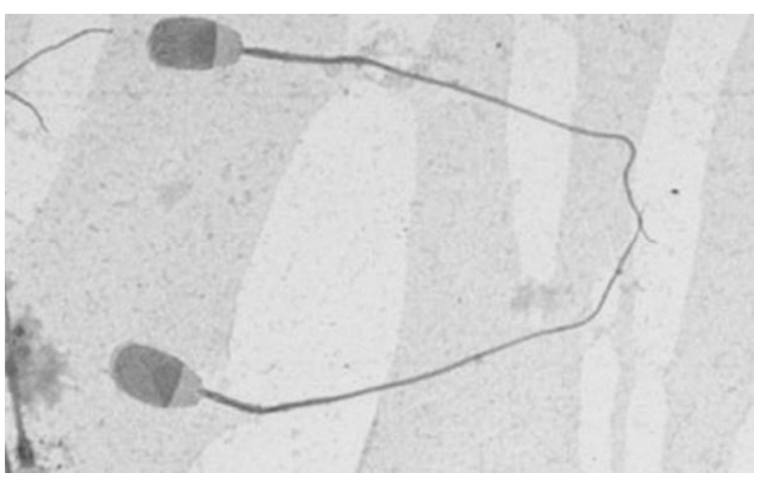

\section{RESULTS AND DISCUSSION}

The analysis of the thermographic images was performed using the FLIR thermal imaging program. The Figure 4 shows the minimum and the maximum temperature of the whole area and the AR01 which is the assigned area (with pink line), showing that the warmest area of the testis is $3{ }^{\circ} \mathrm{C}$ and the coldest is $27.1^{\circ} \mathrm{C}$. The mean temperature (of the testis) is 30.1 ${ }^{\circ} \mathrm{C}$.

Figure 4: An evaluation with FLIR Infrared Camera Software

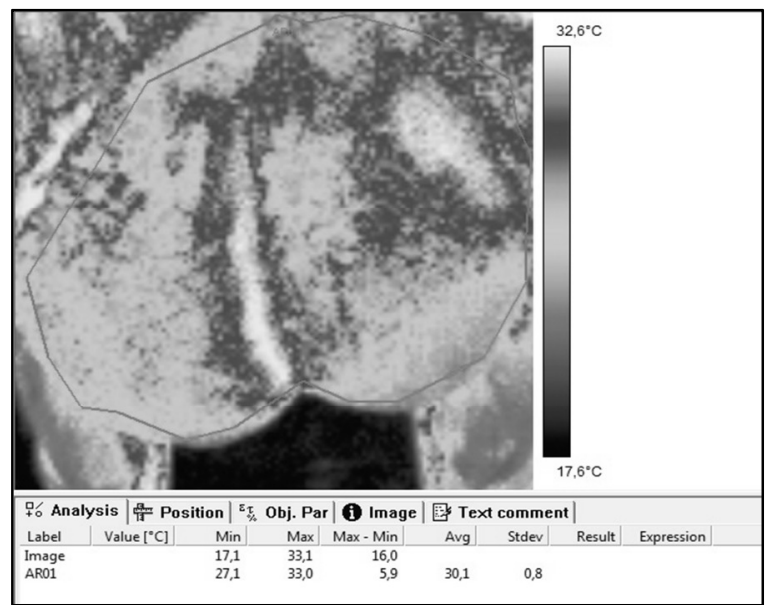

Table 2 shows the minimum, maximum and mean temperatures of the testis in each animal at farm "A". No differences were observed between the items. The identity number 2 Hungarian Large White's testis heat balance evaluation can be seen in Figure 3. 
Evaluation with the FLIR Infrared Camera at the farm "A"

\begin{tabular}{|c|c|c|c|c|}
\hline \multirow[b]{2}{*}{ ID number of animals } & \multirow[b]{2}{*}{ Breed } & \multicolumn{3}{|c|}{ Grey level (GIMP) } \\
\hline & & Mean & $\mathrm{SD}$ & Median \\
\hline ( & HLW* & 188.5 & 38.8 & 191 \\
\hline 2 & HLW & 182.0 & 39.1 & 183 \\
\hline 3 & HLW & 187.4 & 32.9 & 196 \\
\hline 201 & $\mathrm{HL}^{* *}$ & 205.1 & 33.4 & 207 \\
\hline 204 & $\mathrm{HL}$ & 210.3 & 18.9 & 211 \\
\hline 205 & HL & 194.0 & 19.4 & 194 \\
\hline 206 & $\mathrm{HL}$ & 197.6 & 32.6 & 200 \\
\hline
\end{tabular}

*Hungarian Large White, **Hungarian Landrace

The evaluation of ultrasonic pictures was done with the pixel graphic image editing program GIMP (GNU Image Manipulation Program). The echotexture was checked for morphological inhomogeneity. Figure 5 shows normal ultrasonic image of the testis with regular echo pattern including mediastinum testis (M). The GIMP pixel graphic image editing program creates a histogram (Figure 5 on the right) which is useful for the evaluation of the average grey level of the ultrasound image. Due to the 256 grey levels of the ultrasonic images, not only the average grey levels are interesting for image evaluation, but also the different white (dense tissue) and/or black (fluid accumulation) spots. Zero represents black, while 255 refers to the whitest level. As it is shown in Figure 5, the mean value is 181 on the measured area. Table 3 shows mean, dispersion and median values of the Farm " $\mathrm{A}$ " animals.
Figure 5: An Evaluation with GIMP pixel graphic image edition program

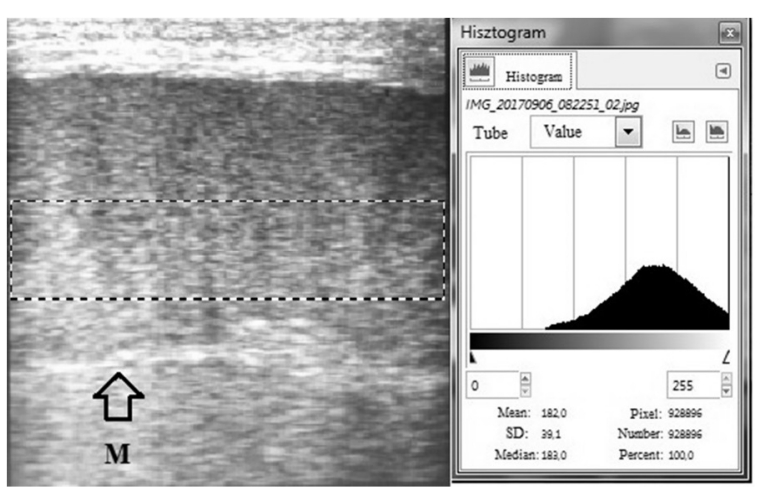

Evaluation with GIMP pixel graphic image edition program at the Farm "A"

\begin{tabular}{|c|c|c|c|c|}
\hline \multirow[b]{2}{*}{ ID number of animals } & \multirow[b]{2}{*}{ Breed } & \multicolumn{3}{|c|}{ Temperature $\left({ }^{\circ} \mathrm{C}\right)$} \\
\hline & & Min. & Max. & Mean \\
\hline 1 & HLW* & 27.7 & 33.6 & 30.5 \\
\hline 2 & HLW & 27.1 & 33.0 & 30.1 \\
\hline 3 & HLW & 24.3 & 33.8 & 29.9 \\
\hline 201 & HL** & 27.2 & 36.2 & 31.2 \\
\hline 204 & HL & 27.1 & 33.1 & 29.5 \\
\hline 205 & HL & 25.7 & 33.8 & 28.8 \\
\hline 206 & HL & 25.0 & 32.4 & 28.9 \\
\hline
\end{tabular}

*Hungarian Large White, **Hungarian Landrace

All ejaculates of the examined animals were analysed for motility using the CASA software (AndroVision, Minitüb, Germany). The software automatically signs the cells with different colours: green means motile cells while red refers to nonmotile cells (Figure 6 on the left). The software generates a report on the measured parameters (motility, composite, sperm concentration, total sperm, total viable sperm, Velocity Average Path (VAP), Distance of Average Path (DAP), Straight Line Distance (DSL), Curvilinear Distance (DCL), Wobble (WOB), Velocity curvilinear (VCL), Velocity straight line (VSL), Linearity (LIN), Beat cross frequency (BCF), Straightness (STR), Amplitude of lateral head (ALH)) (Figure 6 on the right). During the evaluation of sperm cells with the Kovacs-Foote staining method, nine parameters were observed (live, intact acrosome; live, intact and proximal droplet; live, intact and distal droplet; live, intact and abnormal tails; live, damaged acrosome; dead head and live tail; live head and dead tail; dead, damaged and exploded acrosome; detached head or tail). Table 4 shows the absolute live, dead cells and other parameters per farm. 
Figure 6: Evaluation of spermatozoa motility

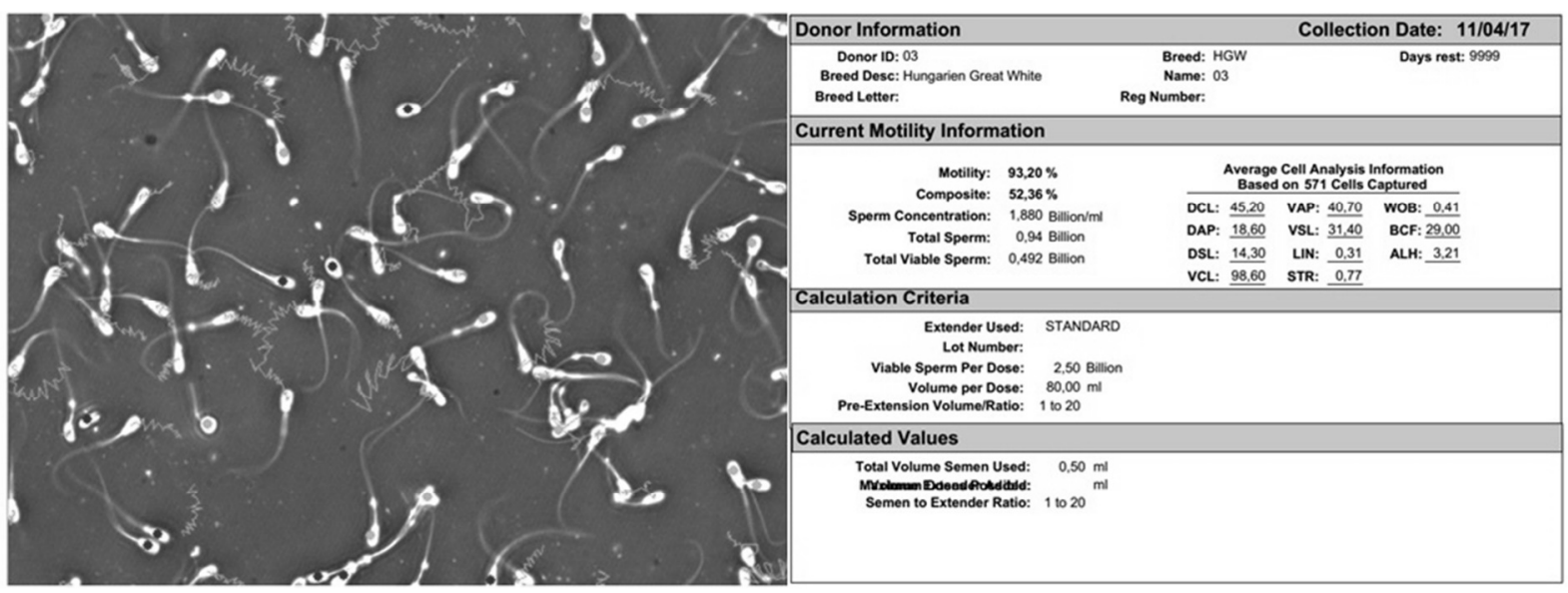

Kovacs-Foote staining method results

\begin{tabular}{|c|c|c|c|c|c|c|c|}
\hline \multirow[b]{2}{*}{ Farm "A" } & \multicolumn{3}{|c|}{$\begin{array}{l}\text { Hungarian Large White } \\
\text { (3 samples/farms) }(\%)\end{array}$} & \multicolumn{4}{|c|}{$\begin{array}{c}\text { Hungarian Landrace } \\
\text { (different samples/farm) }(\%)\end{array}$} \\
\hline & $\mathrm{a}$ & $\mathrm{b}$ & $\mathrm{c}$ & $\mathrm{a}$ & $\mathrm{b}$ & $\mathrm{c}$ & $\mathrm{d}$ \\
\hline live & 37 & 40 & 66 & 60 & 69 & 41 & 65 \\
\hline dead & 42 & 35 & 19 & 21 & 16 & 45 & 25 \\
\hline other abnormalities & 21 & 25 & 15 & 19 & 15 & 14 & 10 \\
\hline Farm "B" & $\mathrm{a}$ & $\mathrm{b}$ & $\mathrm{c}$ & $\mathrm{a}$ & & & \\
\hline live & 15 & 54 & 15 & 6 & & & \\
\hline dead & 9 & 17 & 0 & 45 & & & \\
\hline other abnormalities & 76 & 29 & 85 & 49 & & & \\
\hline Farm "C" & $\mathrm{a}$ & $\mathrm{b}$ & $\mathrm{c}$ & $\mathrm{a}$ & $\mathrm{b}$ & & \\
\hline live & 54 & 30 & 49 & 52 & 83 & & \\
\hline dead & 12 & 17 & 38 & 14 & 11 & & \\
\hline other abnormalities & 34 & 53 & 13 & 34 & 6 & & \\
\hline
\end{tabular}

With the Kovacs-Foote staining method, dead cells, sperm cell abnormalities were found, but there were also good samples with low cell mortality. Among others, the observed abnormalities may result from the time of transporting, weather and dilution. There were some samples which contained many abnormal cells; therefore, samples should be repeatedly taken in the future.

Unfortunately, there was no adequate amount of samples with Gonadotropin-releasing hormone (GnRH) for the correct evaluation.

\section{CONCLUSION}

Following the examination of the reproductive organs of boars and the evaluation of samples, no serious abnormalities were found using ultrasound in the testicular tissue or scrotal thermoregulation by thermography even in ejaculates by CASA. With the Kovacs-Foote staining method the quantity of cells was examined. There were also dead and live spermatozoa but were not extreme abnormalities.
Blood and semen samples are stored on $-20{ }^{\circ} \mathrm{C}$ until genetic SNP chip analysis. The samples collection was inhomogeneous because on some farms did not have the opportunity to make the complete method. For the correct comparative evaluation between farms more experimental sites should be involved where all the necessary data can be collected for a completely homogeneous database.

For complete the present study more boars and samples should be included for further genetic examination in order to demonstrate scientific evidence of association between reproduction performance and genetic markers in Hungarian Large White and Hungarian Landrace boars.

\section{ACKNOWLEDGMENT}

The publication is supported by the EFOP-3.6.3VEKOP-16-2017-00008 project. The project is cofinanced by the European Union and the European Social Fund. Authors gratefully acknowledge financial support (MgF/754/2017). 


\section{REFERENCES}

Alm, K.-Peltoniemi, O.-Koskinen, E.-Andersson, M. (2006): Porcine field fertility with two different insemination doses and the effect of sperm morphology. Reproduction in Domestic Animals. 41. 3: 210-213.

Chen, K.-Baxter, T.-Muir, W. M.-Groenen, M. A.-Schook, L. B (2007): Genetic Resources, Genome Mapping and Evolutionary Genomics of the Pig (Sus scrofa), Review. International Journal of Biological Science. 3. 3: 153-165.

Cobbold, R. S. C. (2007): Foundations of Biomedical Ultrasound. Oxford University Press. 422-423.

Coulter, G. H.-Bailey, D. R. C. (1988): Effects of ultrasonography on the bovine testis and semen quality. Theriogenology. 30. 4: 743-749

Donadeu, M. (2004): Advances in male swine artificial insemination (AI) techniques. The Pig Journal. 54: 110-122.

Einarsson, S.-Larsson, K. (1980): Blood levels of testosterone after $\mathrm{GnRH}$ injection in boars with or without libido. Acta Vet. Scand. 21: 375-379.

Goldberg, B. B.-Kimmelman, B. A. (1988): Medicaldiagnostic ultrasound:aretrospective on its 40th anniversary. Rochester. NY. Eastman Kodak. 1-49.

Horn A. (1976): Állattenyésztés III. Sertéstenyésztés, Baromfitenyésztés, Nyúl- és prémesállat tenyésztés, haltenyésztés. Mezőgazdasági Kiadó. Budapest.

Horn P.-Pászthy Gy.-Bene Sz. (2011): Sertéstenyésztés (szerk. Horn P.) „E-tankönyv” az Állattenyésztő mérnöki alapszak hallgatói számára. A Kaposvári Egyetem, a NyugatMagyarországi Egyetem és a Pannon Egyetem közös kiadása. 165. www.tankonyvtar.hu

McManus, C.-Tanure, C. B.-Peripolli, V.-Seixas, L.-Fischer, V.Gabbi, A. M.-Menegassi, S. R. O.-Stumpf, M. T.-Kolling, G. J.-Dias, E.-Costa, J. G. B. Jr. (2016): Infrared thermography in animal production: An overview. Computers and Electronics in Agriculture. 123: 10-16.

Post, T. B.-Christensen, H. R.-Seifert, G. W. (1987): Reproductive performance and productive traits of beef bulls selected for different levels of testosterone response to GnRH. Theriogenology. 27. 2: 317-328.

Rijsselaere, T.-Van Soom, A.-Maes, D.-de Kruif, A. (2003): Effect of technical settings on canine semen motility parameters measured by the Hamilton-Thorne analyzer. Theriogenology. 60. 8: 1553-1568.
Sarlós P.-Egerszegi I.-Nagy Sz.-Huszár Sz.-Rátky J. (2006): A here endokrin müködésének vizsgálata mangalica kanokon elökísérlet. Állattenyésztés és Takarmányozás. 55. 5: 467-474.

Schinckel, A. P.-Johnson, R. K.-Kittok, R. J. (1984): Testicular development and endocrine characteristics of boars selected for either high or low testis size. Journal of Animal Science. 58. 1: 575-685.

Schnaider L.-Wekerle L.-Fehér T. (1988): Hat hónapos kansüldők herejellemzőinek, szérumtesztoszteron- és kortizolszintjének vizsgálata néhány értékmerő tulajdonság tükrében. Magyar Állatorvosok Lapja. 43. 4: 197-201.

Stalder, K. J.-Knauer, M.-Bass, T. J.-Rothschild, M. F.-Mabry, J. W. (2004): Sow longevity. Pig News and Information. 25: $53 \mathrm{~N}-74 \mathrm{~N}$.

Verstegen, J.-Iguer-Ouada, M.-Onclin, K. (2002): Computer assisted semen analyzers in andrology research and veterinary practice. Theriogenology. 57: 149-179.

Vyt, Ph.-Maes, D.-Rijsselaere, T.-Dejonckheere, E.-Castryck, F.Van Soom, A. (2004): Motility assessment of porcine spermatozoa: a comparison of methods. Reproduction in Domestic Animals. 39: 447-453.

Wekerle L.-Szöllősi E.-Sarlós P.-Schnaider L. (1985): Kanherékből és mellékherékből nyert spermiumok morfológiai vizsgálata. Magyar Állatorvosok Lapja. 40. 11: 663-666.

Wekerle L.-Szöllösi E.-Fehér T. (1989): A kanok termékenyítőképességének előrejelzése GnRH teszttel. Magyar Állatorvosok Lapja. 44. 8: 463-467.

Xiaodong, F.-Yulian, M.-Zhiyong, H.-Yong, L.-Lijuan, H.Yanfeng, Z.-Yue, F.-Yuanxin, Ch.-Xuanting, J.-Wei, Zh.Xiaoqing, S.-Zhiqiang, X.-Lan, Y.-Huan, L.-Dingding, F.Likai, M.-Lijie, R.-Chuxin, L.-Juan W.-Kui, L.-Guangbiao, W.-Shulin, Y.-Liangxue, L.-Guojie, Z.-Yingrui, L.-Jun, W.Lars, B.-Huanming, Y.-Jian, W.-Shutang, F.-Songgang, L.Yutao, D. (2012): The sequence and analysis of a Chinese pig genome. [In: Fang, X. et al. The sequence and analysis of a Chinese pig genome.] GigaScience. 1: 16.

Xu, X.-Pommier, S.-Arbov, T.-Hutchings, B.-Sotto, W.-Foxcroft, G. (1998): In vitro maturation and fertilization techniques for assessment of semen quality and boar fertility. Journal of Animal Science. 76: 3079-3089. 